\title{
Peralihan Aktivitas Pelaksanaan dan Budaya Belajar Semenjak Pandemi di SMA Muhammadiyah 2 Pemalang
}

\author{
Febriyanto Arif Nugroho ${ }^{1}$, Atika Sabardila ${ }^{2}$ \\ PBSI, FKIP, Universitas Muhammadiyah Surakarta ${ }^{12}$ \\ febriyantoan04@gmail.com¹, as193@ums.ac.id ${ }^{2}$
}

\begin{abstract}
Abstrak: Pandemi Covid-19 yang ditetapkan sebagai pandemic global ini selain sudah berdampak pada kegiatan ekonomi, sosial dan politik. Pandemi ini juga sudah memapar sampai dengan tatanan kegiatan belajar mengajar di dunia Pendidikan Indonesia. Tujuan penelitian ini untuk menguraikan dan memaparkan peralihan yang terdampak oleh pandemic, di bidang Pendidikan, yang dilaksanakan pada pelaksanaan pembelajaran daring di SMA Muhammadiyah 2 Pemalang. Metode yang digunakan pada penelitian ini adalah observasi serta dengan menggunakan metode kualitatif untuk melakukan studi kasus saat melaksanakan kegiatan penelitian ini. Pelaksanaan pembelajaran yang dilaksanakan secara daring di SMA Muhammadiyah 2 Pemalang menggunakan media whatsapp group sebagai media belajar daring secara virtual.. Kemudian ada satu dalam keunikan pelaksanaan pembelajaran yang menjadi wujud konsistensi SMA Muhammadiyah 2 Pemalang dalam memaksimalkan pembelajaran daring. Adanya keunikan yakni adanya kegiatan pembinaan wali kelas seminggu sekali yang menjadi wadah konsultasi dan evaluasi guru terhadap pembelajaran yang dilakukan siswanya dirumah, serta keunikan dalam budaya belajar yakni tetap berjalannya kegiatan ekstrakurikuler futsal sebagai salah satu ekstrakurikuler satu-satunya yang masih eksis di masa pandemic ini sebagai wadah silaturahmi antara guru dan siswa di tengah pandemi.
\end{abstract}

Kata Kunci: pandemi covid-19; sistem pembelajaran; pelaksanaan pembelajaran

Abstract: The Covid-19 pandemic, which has been designated as a global pandemic, has had an impact on economic, social and political activities. This pandemic has also exposed the order of teaching and learning activities in the world of Indonesian education. The purpose of this study is to describe and describe the transitions affected by the pandemic, in the field of education, which were carried out in the implementation of online learning at SMA Muhammadiyah 2 Pemalang. The method used in this research is observation and using qualitative methods to conduct case studies when carrying out this research activity. The implementation of online learning at SMA Muhammadiyah 2 Pemalang uses the whatsapp group media as a virtual online learning medium. Then there is one in the uniqueness of the learning implementation which is a form of consistency in SMA Muhammadiyah 2 Pemalang in maximizing online learning. There is a uniqueness, namely the existence of homeroom coaching activities once a week which is a forum for teacher consultation and evaluation of the learning carried out by students at home, as well as the uniqueness in the learning culture, namely the continued running of futsal extracurricular activities as one of the only extracurricular activities that still exist during this pandemic period. a forum for friendship between teachers and students in the midst of a pandemic.

Keywords: covid-19 pandemic; learning system; implementation of learning ... 


\section{Pendahuluan}

Pasti kita semua sudah memahami bahwa pandemic virus covid-19 mewabah hampir merata di seluruh dunia, dan masing-masing pemerintah di seluruh belahan dunia melakukan langkah-langkah yang dapat menekan angka terpaparnya seseorang oleh virus covid-19 ini. Terutama pada fasilitas Pendidikan yang ditutup dikarenakan kegiatan Pendidikan seperti kegiatan belajar mengajar menimbulkan kerumunan dalam pelaksanaan pembelajarannya. Pandemi Covid-19 dapat dikenal sebagai pandemic corona virus yang pada intinya adalah sebuah penyakit baru yang disebabkan oleh jenis coronavirus jenis baru yang ditemukan. Menurut Pandemi global ini telah mengubah segalanya dalam kesehatan, masyarakat, ekonomi, dan pendidikan. Pandemi covid-19 telah mempengaruhi banyak aspek, situasi ini telah merambah sektor pendidikan, dan pemerintah pusat telah memberikan kebijakan untuk membubarkan seluruh institusi pendidikan di tingkat daerah. Hal tersebut dilakukan untuk mencegah penyebaran covid-19.

Pendidikan di Indonesia sendiri saat ini sedang mengalami perubahan, pada masa pandemi sudah tidak memungkinkan lagi untuk melaksanakan kegiatan belajar mengajar di sekolah sesuai dengan praktek sebelumnya. Sejak Presiden Joko Widodo merealisasikan sosialisasi pembelajaran di rumah pada jumpa pers yang diadakan di Istana Bogor saat terjadi pandemi pada 16 Maret 2020, ia telah melaksanakannya di rumah melalui kegiatan Pembelajaran sistem pembelajaran online. Hal tersebut dilakukan untuk mencegah penyebaran virus corona (covid-19) kepada para guru yang merupakan pelaksana pendidikan dan generasi penerus siswa di Diharapkan semua institusi pendidikan tidak melakukan kegiatan seperti biasanya, sehingga dapat meminimalisir penyebaran penyakit covid-19. Negara yang terkena penyakit covid-19 pun melakukan hal serupa.

Kegiatan pelaksanaan pembelajaran yang awalnya dilaksanakan secara tatap muka, ketika pandemic covid-19 muncul pada awal 2020 pelaksanaan pembelajaran langsung dilaksanakan secara daring untuk mengantisipasi penyebaran virus corona ini mewabah awal. Menurut Arsyad, 2011 (Anugrahana, 2020) media pembelajaran online (sering disebut elearning) merupakan media penunjang pendidikan, bukan media alternatif pendidikan. Media online digunakan sebagai media pembelajaran yang dilakukan dalam pelaksanaan pembelajarn di masa pandemi. Siswa dapat melakukan pembelajaran menggunakan media virtual learning atau e-learning seperti google classroom, video coverence, zoom ataupun menggunakan media whatsapp grup untuk digunakan sebagai sarana media pembelajaran (Dewi, 2020). Kondisi demikian memuat seluruh elemen Pendidikan dari mulai dinas terkait hingga para dewan guru dituntut untuk dapat berinovasi dan dapat kreatif dalam menggunakan media pembelajaran daring agar proses transfer ilmu dapat berjalan lancar dan normal.

Fenomena hal baru yang menjadi tantangan bagi para pelaku Pendidikan dari pihak guru pendidik sampai pejabat terkain yang menangani hal ini. Bilfaqih dan Qomarudin, 2015 (dalam Jayul dan Irwanto, 2020) mendefinisikan pembelajaran online sebagai pembelajaran yang memanfaatkan teknologi multimedia, video, kursus virtual, teks animasi online, pesan suara, email, telekonferensi dan streaming video online untuk pembelajaran.Itu bisa dilakukan secara gratis atau berbayar.. Seperti yang dipaparkan oleh Menurut Nasional (dalam Gusty Sri dkk., 2020), Menteri Pendidikan dan Kebudayaan Republik Indonesia segera menindaklanjuti melalui Surat Edaran No.10. Resolusi Nomor 4 Tahun 2020 tersebut memuat penjelasan agar proses pengajaran dapat dilaksanakan di rumah atau dalam yang disebut pembelajaran jarak jauh atau online untuk memutus mata rantai penularan virus corona. 
Pelaksanaan pembelajaran yang dilaksanakan di sekolah meliputi kegiatan pra kondisi pembelajaran, pendekatan dan strategi dalam melaksanakan kegiatan pembelajaran yang diterapkan oleh guru sebagai bahan ajar, pengembangan materi dan sumber belajar, pengembangan lembar kerja siswa,pengembangan media pembelajaran dan media penilaian yang diterapkan oleh guru. Dalam pelaksanaan pembelajaran ini seluruh elemen Pendidikan seperti di desak untuk lepas dari zona nyaman, maksudnya pembelajaran yang awalnya dilaksanakan secara tatap muka di sekolah, setelah muncul pandemic ini mengharapkan segala sector kehidupan khususnya sector Pendidikan dilakukan dari rumah secara virtual. Segala sesuatu dalam pelaksanaan pembelajaran daring ini dapat sukses bergantung pada karakteristik peserta didik. Motivasi peserta didik berperan besar dalam mensukseskan pembelajaran daring ini. Penggunaan teknologi informasi juga dapat membantu pelaksanaan pembelajaran daring ini seperti yang dijelaskan Wekke \& Hamid, 2013 (dalam Khusniyah, 2019) berpendapat bahwa teknologi informasi dapat diterima sebagai media dalam proses pendidikan, termasuk membantu proses belajar mengajar, termasuk mencari referensi dan sumber informasi.

Masalah yang sering timbul dari siswa adalah bahwa tak sedikit siswa yang bosan dengan sistem pembelajaran jarak jauh ini. Beberapa siswa menurut guru juga sangat berharap pembelajaran bisa dijalankan secara tatap muka kembali agar mereka dapat melihat langsung sosok gurunya, mendengarkan langsung apa yang guru sampaikan dan bertanya langsung ketika ada materi yang belum dipahami. Tetapi pada daring ini tidak ada instruksi secara langsung antara guru dan siswa maka dinilai tranfer pengetahuannya kurang ketika di dalam forum pembelajaran. Banyak siswa juga yang tidak mempunyai perangkat sebagai penunjang pembelajaran jarak jauh ini, selain itu banyak pula orang tua yang merasa keberatan dengan biaya untuk membeli kuota belajar, maka dari itu pihak sekolah hanya mengadakan pembelajaran daring lewat aplikasi whatsapp grup atau google classroom saja yang dinilai masih dapat dijangkau semuanya.

Permasalahan juga dikeluhkan oleh pihak guru sebagai pendidik pun mengalami kendala, diantaranya banyak guru yang belum melek teknologi yang menyebabkan sebagaian guru belum terbiasa menggunakan perangkat teknologi dalam pelaksanaan pembelajaran jarak jauh atau dalam jaringan tersebut. Selain itu, guru mengakui pada pandemi ini pembelajaran sangat susah untuk berjalan efektif, waka kurikulum SMA Muhammadiyah 2 Pemalang mengatakan serba susah dalam keadaan seperti ini, seperti bentuk penguatan pendidikan karakter kepada siswa sulit untuk dijalankan dan dicontohkan. Hal tersbut sesuai dengan pendapat menurut (Rigianti, 2020) bahwa beberapa guru mengeluhkan kendala yang dialami ketika melakukan pembelajaran daring ini diantaranya kendala aplikasi pembelajaran virtual, kendala jaringan internet ketika mengajar, serta ketersediaan sarana seperti gawai yang terbata, pengelolaan, penilaian dan pengawasan pembelajaran daring yang terkendala karena dilakukan secara virual dan berjauhan. Memang terkait knowledge atau pengetahuan masih bisa diatasi oleh peserta didik karena aspek itu siswa bisa mempelajarinya secara mandiri, tetapi untuk aspek spiritualnya, untuk hal-hal yang menyangkut kepribadian siswa, seperti jiwa sosialnya, tanggung jawab, disiplin, jujur, berakhlak mulia pada pembelajaran jarak jauh ini susah untuk ditanamkan dari guru karena pembelajaran hanya sebatas lewat google classroom, whatsapp grup, dan Microsoft teams yang hambatannya adalah sulitnya untuk memberikan contoh secara langsung kepada siswa terkait bentuk internalisasi pendidikan karakter kepada setiap peserta didik.

Dalam pelaksanaan penelitian ini memiliki beberapa tujuan dari pelaksanan penelitian ini, diantaranya: 
1. Mendeskripsikan pelaksanaan pembelajaran, dan langkah sekolah terhadap kegiatan pelaksanaan belajar mengajar tetap berlangsung.

2. Memaparkan keunikan pelaksanaan pembelajaran daring di masa pandemic.

SMA Muhammadiyah 2 Pemalang didirikan tanggal 15 Juli 1985 tahun ajaran 1985/1986 berlokasi di Dukuh Sirandu RT. 02 RW. 07 Desa Bojongbata Kecamatan/Kabupaten Pemalang, dengan luas tanah kurang lebih $4050 \mathrm{M}^{2}$. Pelaksanaan pembelajaran terutama di SMA Muhammadiyah 2 Pemalang ini tentunya tidak seluruhnya selalu berjalan mulus sesuai apa yang diharapakn sebelumnya. Dalam pelaksanaanya permasalahan itu tumbul dan permasalahan itulah yang hendaknya harus selalu peka teradap adanya pelaksanaan pembelajaran daring ini dengan mengembangkan kurikulum yang menyesuaikan keadaan yang ada. Artinya pihak sekolah serta dewan guru Bersama dengan peserta didik hendaknya selalu memiliki inisiatif dalam menembangkan dan menjaga kegiatan pembelajaran tetap berjalan baik dan tetap tidak kehilangan dari nilai utama Pendidikan yakni sebagai saran transfer ilmu dan aspek penguatan karakter dari siswa, serta sesuai tujuan awal Pendidikan walaupun pelaksanaan kegiatan belajar mengajar tidak dilaksanakan seperti biasanya, dan hanya dilaksanakan secara daring.

Berdasar dari uraian diatas, maka penelitian ini akan menguraikan serta menjelaskan mengenai peralihan pelaksanaan pembelajaran atas dampak covid-19 di tingkat Pendidikan SMA di Kota Pemalang

\section{Metode Penelitian}

Penelitian ini menggunakan metode kualitatif untuk melakukan studi kasus saat melaksanakan kegiatan penelitian ini. Menggunakan studi kasus untuk menggambarkan masalah yang dapat memengaruhi hasil penelitian ini pada pembaca. Menurut penjelasan dalam Hodgetts, dan Stolte, 2012 (Satrianingrum, 2021: 635), Studi kasus menggambarkan apa yang terjadi dengan menjelaskan apa yang terjadi dalam kelompok sehingga dapat memberikan informasi penting, sedangkan metode kualitatif bertujuan untuk mengungkap keunikan individu, kelompok, komunitas dan / atau organisasi dalam kehidupan sehari-hari, secara detail, dan mendalam. Cara dan bertanggung jawab atas sains.

Gumilang (2016: 145) menjelaskan bahwa secara umum definisi penelitian kualitatif adalah pendekatan multikarir, melibatkan metode eksplanatori dan wajib untuk setiap topik yang disampaikan. Ini berarti penelitian kualitatif bekerja dalam setting yang alami, yang berupaya untuk memahami, memberi tafsiran pada fenomena yang dilihat dari arti yang diberikan orang-orang kepadanya. Metode kualitatif digunakan untuk mengungkap sifat pengalaman seseorang dengan fenomena tertentu. Hal itu sesuai dengan apa yang dijelaskan menurut Mantra di buku Moleong dalam Siyoto dkk (2015: 28) mengusulkan metode kualitatif seperti program penelitian untuk menghasilkan deskripsi dalam bentuk kata-kata manusia atau kata-kata untuk mengamati perilaku. Selain itu, menurut Strauss dan Corbin, 2003 (Lismarwan \& Fuad, 2010: 6) menjelaskan metode kualitatif yang sedikit diketahui, yang juga dapat digunakan untuk mengungkapkan atau tidak ada yang diketahui dalam suatu fenomena. Cara ini juga bisa digunakan untuk menambah pengetahuan yang sedikit diketahui.

Pada pelaksanaan ini objek yang saya amati adalah bagaimana pelaksanaan pembelajaran yang dilaksanakan di SMA Muhammadiyah 2 Pemalang di masa pandemi. 


\section{Hasil dan Pembahasan}

Penelitian ini dilaksanakan di SMA Muhammadiyah 2 Pemalng. Serta mengidentifikasi permasalahan yang timbul dari pelaksanaan pembelajaran daring ini seperti permasalahan yang timbul akibat keterbatasan media daring untuk media pembelajaran daring. Berdasarkan data yang sudah dihimpun melalui wawancara dengan guru SMA Muhammadiyah 2 Pemalang dan mengamati langsung pelaksanaan pembelajaran yang dilaksanakan setiap harinya, serta mengamati seperti apa perbedaan pembelajaran daring yang dilaksanakan dan mengomparasikan dengan hasil wawancara dengan narasumber mengenai pelaksanaan pembelajaran sebelum terjadinya pembelajaran daring karena pandemi covid-19 ini. Hasil data penelitian dapat dirincikan dan dijelaskan, sebagai berikut:

\subsection{Pelaksanaan Pembelajaran Daring di Masa Pandemi}

\subsubsection{Perencanaan atau Prakondisi Pembelajaran}

Terkait prakondisi pembelajaran sebelum pandemi jika masuk pada jam pertama guru memimpin berdoa terlebih dahulu, membaca ayat suci Al-Quran dan menyanyikan lagu wajib yang sudah dijadwalkan, setelah itu langsung masuk ke materi. Pada pandemi sekarang ini hal itu tidak berjalan dan hanya langsung memberikan materi dan tugas melalui whatsapp grup dan google classroom ketika sudah masuk jadwal jam pelajaran. Kemudian, berkaitan dengan RPP guru membentuk RPP selama per satu kali pertemuan, kemudian juga ada RPP untuk 5 minggu atau 5 kali pertemuan. Jam pembelajaran Bahasa Indonesia normalnya ketika sebelum pandemi dalam setiap minggu dilaksanakan selama 4 jam dengan alokasi satu jamnya 45 menit.

\subsection{Metode Pelaksanaan Daring}

3.2.1 Pengimplementasian Model, Taktik Pembelajaran

Mengenai strategi pembelajaran dan teknik, anak kadang diminta untuk bertanya pertanyaan tentang materi pembelajaran yang telah dipelajari sebelum memasukkan materi untuk penjelasan. Selama pandemi ini, teknik mengajar hanya memberikan materi dan perintah tugas (mencatat / mengerjakan soal) di google classroom dan whatsapp grup. 3.2.2 Media Pembelajaran

Pemilihan dan Pengembangan Materi Sumber Belajar yang digunakan pada SMA Muhammadiyah 2 Pemalang ini menggunakan buku paket dan LKS serta terkadang menggunakan referensi hasil MGMP yang berupa link lalu nanti di copy paste oleh guru dan dicetak Sedangkan, ketika berkaitan dengan materi referensi yang membutuhkan mencari di koran maka guru membawa ke perpustakaan untuk mencari sumber dari koran, terkadang juga diperbolehkan membuka internet ketika diperlukan saja untuk mencari referensi.

3.2.3 Penyusunan dan Pengenmbangan Lembar Kerja Peserta Didik (LKPD) Mengenai Lembar Kerja Peserta Didik, guru SMA Muhammadiyah 2 Pemalang menggunakan LKS dan buku tugas yang telah dibuat, tugas kelompok maupun individu juga merupakan bagian dari LKPD.

\subsection{Pemilihan, Pengembangan Media Pembelajaran dan Penilaian}

Pemilihan media pembelajaran,yang digunakan oleh SMA Muhammadiyah 2 Pemalang yang biasanya dilaksanakan sebelum pandemi terkadang menggunakan LCD 
proyektor ketika memang materi itu membutuhkan untuk ditampilkan secara audio visual, tetapi jika tidak maka hanya menerangkan (ceramah) dan memberikan contoh lewat sumber belajar buku paket ataupun LKS. Bentuk penilaian, para guru menilai dari daftar kehadiran, tugas-tugas dalam buku tugas, keaktifan di kelas (sebelum pandemi), UTS, dan UAS lalu dihasil akhirkan. Di masa pandemi sekarang ini daftar kehadiran ditandai dengan siswa mengerjakan tugas, dan keaktifan sulit untuk dilihat karena pembelajaran tidak memakai tatap muka virtual.

\subsection{Kultur Persekolahan}

3.4.1 Pelaksanaan Kultur Budaya Sekolah Sebelum dan Sesudah Pandemi

a. Kegiatan budaya belajar yang meliputi kultur persekolahan/budaya warga sekolah yang dilakukan sebelum masa pandemi dan sesudah terdampak pandemi.

b. Kultur persekolahan yang dilakukan SMA Muhammadiyah 2 Pemalang sebelum masa pandemi dari awal masuk sekolah/gerbang sekolah diantaranya:

c. Masuk gerbang sekolah siswa disambut oleh guru yang ditugaskan oleh sekolah untuk piket menyambut siswa untuk bersalaman didepan gerbang sekolah.

d. Kegiatan setelah masuk di kelas kemudian melakukan doa sebelum belajar, melakukan tadarus Al-Quran Juz 30 terjadwal, setelah selesai tadarus kemudian menyanyikan lagu kebangsaan dan mars Muhammadiyah.

e. Shalat Duha dengan didampingi guru piket terjadwal, apabila kelas yang terjadwal melakukan sholat Duha terpantau tidak melaksanakan maka akan ditindak lanjuti oleh guru piket yang ditugasi untuk memantau tersebut.

f. Salat Jumat berjamaah yang dilaksanakan secara wajib oleh warga sekolah. Untuk wali kelas agar selalu mendampingi anak didiknya. Apabila tidak melaksanakan maka akan ada punishmet dari wali kelas untuk yang tidak melaksanakan sholat Jumat.

g. Ekstrakurikuler SMA Muhammadiyah 2 Pemalang ada beberapa macam, yaitu OSIS/IPM, English Club, Tapak Suci, Bola Volly, Panahan, Hizbul Wathan, panahan, dan futsal.

Untuk kegiatan kultur persekolahan di era pandemi ini tidak berjalan maksimal. Hanya beberapa yang masih berjalan dengan beberapa penysuaian dalam pemberlakuannya yang di sesuaikan dengan era new normal dimana tetap memperhatikan dan mematuhi protokol Kesehatan. Kegiatan ekstrakurikuler yang masih berjalan di era pandemi ini, diantaranya: English Club (secara terbatas) dan Futsal. Hal tersebut dikarenakan kegiatan ekstrakurikuler tersebuh memberikan wadah untuk anak agar menjadi pendorong dan menjadi wadah bagi siswa didik SMA Muhammadiyah 2 Pemalang ini semakin mengasah dan mendalami tentang keterampilannya yang lebih baik lagi. Untuk kegiatan kultur persekolahan di era pandemi ini tidak berjalan maksimal. Hanya beberapa yang masih berjalan dengan beberapa penysuaian dalam pemberlakuannya yang di sesuaikan dengan era new normal dimana tetap memperhatikan dan mematuhi protokol Kesehatan. Kegiatan ekstrakurikuler yang masih berjalan di era pandemi ini, diantaranya: English Club (secara terbatas) dan Futsal. Hal tersebut dikarenakan kegiatan ekstrakurikuler tersebuh memberikan wadah untuk anak agar menjadi pendorong dan menjadi wadah bagi siswa didik SMA Muhammadiyah 2 
Pemalang ini semakin mengasah dan mendalami tentang keterampilannya yang lebih baik lagi.

\subsection{Kegiatan Seremonial yang Dilaksanakan Pihak Sekolah di Masa Pandemi}

Kegiatan seremonial formal yang dilaksanakan SMA Muhammadiyah 2 Pemalang seperti upacara bendera rutin hari Senin dan apel pagi ditiadakan karena pandemi dilarang membuat kerumunan. Namun, untuk rapat dewan guru dan kepala sekolah yang sifatnya urgent masih dilakukan dengan mengedepankan protokol Kesehatan 3M. Serta, untuk kegiatan pelantikan organisasi sekolah seperti IPM (katan Pelajar Muhammadiyah) dan lainnya bisa menggunakan luring dengan mematuhi protokol Kesehatan. Serta untuk upacara hari besar dilakukan secara virtual dengan menyimak via zoom.

\subsection{Peran Guru sebagai Pendidik, Pembimbing, Teladan, Pembiasa, Pengontrol, Fasilitator, Motivator, Inovator.}

3.6.1 Guru sebagai Pendidik di Masa Pandemi

Peran guru sebagai pendidik menuntut guru untuk menjaga otoritas, tanggung jawab, disiplin, kemandirian, dan kepribadian yang baik agar dapat menjadi panutan bagi siswa (Surahman, 2017). Pengimplementasian Guru sebagai pendidik dalam masa sebelum pandemi guru tidak hanya mengajar atau memberikan suatu materi saja serta memberi contoh suri tauladan saja, misalnya pada saat KBM di jam pertama sebelum masuk pembelajaran siswa diperintahkan untuk berbaris kemudian salim dengan bapak atau ibu guru yang ingin masuk dalam jam pertama, jika sudah masuk ke kelas pelajaran di awali dengan membaca doa dan jika selesai membaca doa siswa dibudayakan dengan gerakan literasi yaitu dengan membaca Al Qur'an disetiap harinya. Dapat dikatakan bahwa guru tidak hanya mengajar, mengajar dalam artian hanya memberikan materi melaikan guru juga memberikan nilai. Seperti berbaris dan salim, siswa diberikan nilai yang dapat dipetik antara lain belajar budaya antri, sabar, dan juga hormat kepada orang yang lebih tua. Dalam pelaksanaan baca Al Qur'an juga merupakan suatu nilai agama yang sangat baik yang dapat ditanamkan dalam diri siswa sehingga menjadi kebiasaan yang dapat diterapkan dirumah. Pada masa pandemi seperti sekarang ini sangat sulit mencontohkan guru sebagai pendidik karena hanya memberikan materi saja.

3.6.2 Guru sebagai Pembimbing

Peran guru pembimbing harus lebih diperhatikan, karena keberadaan guru di sekolah adalah untuk membimbing siswa menjadi orang yang cakap, terampil, dan dewasa yang berakhlak mulia dan berakhlak mulia. Tanpa bimbingan, siswa akan mengalami kesulitan dalam menghadapi perkembangannya sendiri (Darmadi, 2015). Pengimplementasian peran guru sebagai pembimbing sebelum adanya pandemi dapat dikatakan berlangsung baik karena guru mengawasi dan juga mengarahkan siswa untuk berperilaku baik. Seperti misalkan dalam suatu pelajaran dikelas guru tidak hanya memberikan suatu materi dan ilmu pengetahuan mengenai suatu mata pelajaran melainkan guru juga mengawasi siswa jika dalam kelas pada saat guru menerangkan siswa bermain hp, juga saat anak yang terlambat. Guru berkewajiban menegur dan memberikan suatu pengertian bahwa hal yang dilakukan oleh siswa tersebut merupakan suatu hal yang salah dan jangan diharapkan tidak diulangi. Pada dasarnya belajar merupakan suatu proses bukan hanya memperluas pengetahuan mengenai materi, melainkan juga untuk mencari nilai dan dalam suatu proses tentu harus ada bimbingan 
maka dari itu guru sebagai pembimbing dapat dikatakan bahwa guru memiliki kewajiban untuk mengarahkan peserta didiknya agar lebih baik dari sebelumnya.

3.6.3 Guru sebagai Teladan

Pada implementasinya guru sebagai teladan dapat dikatakan bahwa guru merupakan suatu sosok yang digunakan sebagai contoh bagi siswanya. Guru harus mencontohkan hal yang baik agar tidak menjadi bumerang untuk guru itu sendiri. Karena siswa juga dapat mencontoh gurunya seperti halnya pada cara berpakian. Misalnya guru menyuruh anak untuk tidak menggunakan jilbab langsung pakai, maka guru tersebut harus menerapkanya pada dirinya sendiri sebelum meminta orag lain untuk melakukanya. Keterlambatan juga dapat ditiru oleh peserta didik karena jika ada seorang guru yang sering terlambat maka akan menjadi patokan atau tokoh yang ditiiru oleh siswa untuk melakukan keterlambatan

\subsubsection{Guru sebagai Pembiasa}

Implementasi guru sebagai pembiasa dimaksudkan bahwa guru harus membiasakan para peserta didik untuk meningkatkan kesadaranya kepada hal-hal yang baik, seperti contohnya pada lingkungan sekitar, seperti halnya guru mencontohkan murid atau siswanya agar tidak terlambat, karena sekolah memberikan sanksi kepada siswa yang terlambat dan menyuruh mereka untuk memungut sampah yang berserakan juga rumput-rumput yang mulai panjang yang notabenenya tidak terurus. Dalam hal membiasakan ini guru memberikan suatu pengertian bahwa jangan terlambat karena jika terlambat maka akan diberi sanksi. Dan juga siswa dibiasakan tidak boleh membuang sampah sembarangan.

\subsubsection{Guru sebagai Pengontrol}

Pengimplementasiannya guru media pengontrol siswanya, masing-masing guru memiliki daftar panduan untuk mengontrol sikap anak. Dari kurikulum sendiri meliputi nilai sikap, nilai pengetahuan kognitif, dan absensi. Semua itu merupakan satu kesatuan yang tercover di daftar nilai. Untuk nilai sikap lebih ditekankan oleh guru BK, guru PPKn dan guru Agama (bagaimana cara menindaklanjuti anak) jika tidak ada perubahan, maka guru akan memanggil orang tua anak tersebut. Masing-masing guru harus mempunyai catatan daftar nilai yang tertulis sebagai bukti fisik guru telah mengontrol siswa.

\subsubsection{Guru sebagai Fasilitator}

Sebagai fasilitator, guru dapat merangsang atau memberikan stimulus rangsangan untuk membantu siswa belajar sendiri (Alawiyah, 2013). Sesuai dengan pendapat tersebut seorang guru hendaknya harus memiliki pemahaman tentang pengetahuan dan kelemahan masing-masing siswa, hal ini sangat diperlukan guru untuk dapat memberikan bantuan dan memfasilitas sesuai minat dan kebutuhan siswanya. Perlu dipahami bahwa setiap siswa memiliki minat bakat yang berbeda serta gaya dan metode belajar terbaik mereka yang memerlukan fasilitas serta sumber daya yang berbeda pula. Dalam pengimplementasian peran guru sebagai fasilitator, SMA Muhammadiyah 2 Pemalang menerima peserta didik yang mengalami kendala dalam hal pelaksanaan pembelajaran daring untuk datang ke sekolah dan melaksanakan bimbingan secara intens dalam hal tugas atau pendalaman materi terhadap guru mata pelajaran dan atau dengan wakil kepala sekolah urusan kurikulum apabila ada siswa yang bermaslaahan dalam pembelajaran daring ini. 


\subsubsection{Guru sebagai Motivator}

Sebagai motivator, guru harus bisa mendorong peserta didiknya agar tumbul semangat untuk aktif mengikuti pembelajaran. Sebagai motivator, guru hendaknya dapat mentimulus peserta didiknya agar timbul gairah untuk aktif mengikuti pembelajaran (Darmadi, 2015). Menurut pendapat (Juhji, 2016) menguraikan bahwa dalam sebuah proses pembelajaran. motivasi merupakan salah satu aspek dinamis yang sangat penting. Sering terjadi peserta didik yang kurang berprestasi bukan disebabkan kemampuannya yang kurang, tetapi dikarenakan tidak adanya motivasi untuk belajar. Dengan demikian, peserta didik yang berprestasi rendah belum tentu disebabkan oleh kemampuannya yang rendah pula, tetapi mungkin disebabkan tidak ada dorongan motivasi dalam dirinya (motivasi instrinsik). Guru hendaknya sangat ekstra menghadapi berbagai macam sifat peserta didiknya. Tidak hanya untuk mencari prestasi, siswa ingin belajar saja harus diberi motivasi yang luar biasa. Guru harus memiliki hati nurani didalam 'bagaimana kita harus mengubah anak menjadi baik'. Harus ada pendekatan kepada siswa, karena penanganan setiap anak itu berbeda-beda, sehingga harus memiliki pendekatan yang sangat ekstra. Proses belajar mengajar akan berhasil apabila siswa di dalamnya terdapat motivasi yang tinggi. Oleh karena itu, guru berperan penting dalam menumbuhkan motivasi pada peserta didiknya, serta semangat di dalam diri dan hati siswa untuk belajar.

\subsubsection{Guru sebagai Inovator}

Sebagai inovator, guru dapat menjelaskan pengalaman yang didapatkannya di masa lalu ke dalam kehidupan yang lebih bermakna untuk peserta didiknya. Guru mesti mempunyai metode belajar yang kreatif dan inovatif dalam menyampaikan materi. Dan juga memikirkan bagaimana cara menyampaikan materi kepada anak, yang tidak membuat mereka bosan. Dalam inovasi pendidikan, guru ditempa dengan tuntutan agar selalu mencoba, mengubah, megembangkan, dan meningkatkan gayanya mengajar agar dapat menuangkan model pengajaran yang cocok serta sesuai dengan apa yang diharapkan peserta didik.

\subsection{Keunikan dalam Pelaksanaan Pembelajaran dan Budaya Belajar di SMA Muhammadiyah 2 Pemalang}

Pembelajaran adalah sebuah kegiatan utama dalam sebuah proses pendidikan (Hanafy, 2014). Dalam kegiatan pembelajaran diharapkan terjadi sebuah interaksi antara peserta didik dengan guru yang menyampaikan materi secara lisan, tertulis, dan atau visual melalui media penunjang. Seperti pendapat yang dijelaskan oleh (Syarifudin, 2020) berpendapat bahwa kegiatan pembelajaran adalah sebuah proses Internalisasi ilmu ke dalam skema siswa. Dalam prosesnya terdapat aktivitas siswa Sebagai siswa, ada aktivitas guru Sebagai pembelajar. Inovasi dan kratifitas seorang guru di uji dalam membuat inovasi pembelajaran yang terpadukan dan terbarukan demi menciptakan pembelajaran yang sesuai dengan tujuan pendidikan itu sendiri.

Dilihat dari segi pelaksanaan pembelajaran yang dilaksanakan pada SMA Muhammadiyah Pemalang memiliki keunikan tersendiri dalam pelaksanaannya. Dalam hal ini keunikan yang dimaksud adalah pihak sekolah yang berinisiatif melaksanakan kegiatan bimbingan wali kelas yang dilakukan guna memantau kegiatan daring yang dilaksanakan siswa dirumah. Kemudian, bimbingan wali kelas ini juga menghimpun dan memantau tugas-tugas serta catatan yang diberikan oleh guru saat pembelajaran daring dirumah. Dalam pelaksanaan bimbingan wali kelas yang dilaksanakan rutin setiap minggu 
ini digagas langsung oleh Kepala Sekolah dengan diusung oleh Wakil Kepala sekolah bidang Humas, Kurikulum dan Kesiswaan.

Pelaksanaan bimbingan wali kelas ini pada intinya bertujuan untuk memantau kegiatan pembelajaran yang dilakukan siswa dirumah. Agar siswa dapat terpantau progres pengerjaan tugasnya. Kemudian, pelaksanaan bimbingan wali kelas ini dilaksanakan juga sebagai sarana sharing materi yang belum dipahami siswa selama seminggu yang lalu. Kemudian materi tersbut diulang oleh guru bersangkutan agar siswa memahami secara maksimal inti materi yang disampaikan hal tersebut inisiatif pihak sekolah untuk dapat mewujudkan pendidikan karakter peserta didik yang baik, walaupun pelaksanaan pembelajaran dilaksanakan secara daring di rumah namun kejujuran dan kedisplinan dalam mengerjakan tugas secara tepat waktu dan jujur menjadi tolak ukur terselenggaranya kegiatan bimbingan wali kelas ini.

Begitu pula dengan metode evaluasi yang digunakan dalam pelaksanaan pendidikan karakter ini, yang harus dilaksanakan termasuk nilai-nilai yang telah diperoleh siswa di dalam pembelajaran. proses dan di lingkungan sekitarnya (Citra, 2012). Dalam pelaksanaan pembelajaran dari ini pihak sekolah hendaknya tetap menjadi pelaksana pendidikan yang solutif dalm pelaksanaan pembelajaran yang terpadukan. (Anggraeni, 2018) berpendapat bahwa dengan kata lain kualitas pembelajaran akan sangat ditentukan oleh kualitas perencanaan pembelajaran yang digunakan.

\subsection{Keunikan Pelaksanaan Budaya Belajar}

Budaya belajar adalah suatu ciptaan manusia yang memunculkan suatu tingkah laku tentang belajar, digunakan oleh seseorang atau sekelompok orang untuk menunjukkan tindakan dan tindakan di lingkungan sekolah (Nugraha, 2018). Seperti yang dijelaskan pula oleh (Nugraha, 2018) berpendapat bahwa pengembangan budaya belajar dapat dicapai dengan mengembangkan lingkungan sekolah komunitas. Pengembangan budaya belajar dapat dipengarugi dari berbagai macam factor, factor internal (psikologis) peserta didik atau factor lingkungan sekitar sekolah (eksternal) yang mendorong keberbagaian proses budaya belajar (Arif, 2011). Siswa hidup dan mengembangkan diri dalam lingkungan sosial komunitas sekolah, sehingga perkembangan suatu pembelajaran hanya dapat berlangsung dalam lingkungan sosial komunitas sekolah yang bersangkutan.

Mengenai keunikan, terdapat keunikan tersendiri pada SMA Muhammadiyah 2 Pemalang dalam hal budaya belajar, yakni tetap melaksanakan kegiatan ekstrakurikulerrutin yang dilaksanakan pihak sekolah dengan inisiatif siswa dan guru. Terkait pelaksanaan kegiatan futsal rutin ini terlihat keakraban antara guru dan siswa. Dalam hal ini antara siswa dan guru yang ikut serta dalam kegiatan futsal tersebut seperti tidak ada halangan dan tidak ada kasta siswa dan guru. Metode yang digunakan guru untuk lebih bisa saling bergaul atau bersosial dengan cara tidak harus menggunakan sesuatu yang formal di luar jam pembelajaran. Hal itu tampak ketika di ekstrakurikuler futsal yang diadakan setiap hari Rabu (opsional). Terlihat guru dan siswa saling bercanda Bersama dan siswa juga tidak merasa terlalu formal asalkan tetap mengindahkan tata krama siswa dengan gurunya. Terlihat bahwa dalam pelaksanaan futsal ini dalam hal kekeluargaan terjalin sangat erat guna memupuk persaudaraan dan menguatkan tali silaturahmi antara guru, siswa, dan alumni. Terlihat pada saat melakukan observasi ada beberapa alumni yang antusias mengikuti kegiatan futsal ini. Karena hanya futsal lah ekstrakurikuler yang masih berjalan di masa pandemic ini, di mana saat pandemic ini 
segala sesuatu haruslah menghindari kerumunan dan selalu melakukan jaga jarak (social distancing).

\section{Kesimpulan dan Saran}

Tentunya dalam pelaksanaan langsung dilapangan, proses pelaksanaan kegiatan belajar mengajar (termasuk pelaksanaan kegiatan belajar mengajar dan budaya sekolah) sebelum pandemi Covid-19 tidak berjalan seperti biasanya. Fakta mengatakan bahwa dalam pembelajaran jarak jauh atau setelah penerapan jaringan ini, baik guru sebagai pendidik maupun siswa sebagai peserta didik telah menimbulkan beberapa masalah teknis yang dapat menyebabkan terhambatnya kegiatan pembelajaran, dengan adanya inovasi terbarukan yang selalu dibuat oleh pihak sekolah dan selalu diperbaharui setiap saat maka segalanya akan terlihat mudah dan pelaksanaan pembelajaran daring akan berhasil dan sesuai dengan tujuan Pendidikan, serta inovasi itulah yang akan menekan permasalahan klasik yang terjadi pada saat pelaksanaan pembelajaran daring ini.

\section{Daftar Pustaka}

Alawiyah, Faridah. 2013. Peran Guru dalam Kurikulum 2013. Aspirasi: Jurnal MasalahMasalah Sosial. Vol. 4, No. 1

Anggraeni, P; Aulia, Akbar. 2018. Kesesuaian Rencana Pelaksanaan Pembelajaran dan Proses Pembelajaran. Jurnal Pesona Dasar. Vol. 6, No. 2

Anugrahana, Andri. 2020. Hambatan, Solusi dan Harapan: Pembelajaran Daring Selama Masa Pandemi Covid-19 oleh Guru Sekolah Dasar. Jurnal Pendidikan dan Kebudayaan. Vol 10 No. 3

Arif, Saiful. 2011. Budaya Belajar Siswa pada Sekolah Unggul di SMA Negeri 1 Pamekasan. Nuansa: Jurnal Penelitian Ilmu Sosial dan Keagamaan Islam. Vol. $\quad$ 8, No. 2

Citra, Yulia. 2012. Pelaksanaan Pendidikan Karakter dalam Pembelajaran. JUPHEKU: Jurnal Penelitian Pendidikan Khusus. Vol. 1, No. 1

Darmadi, Hamid. 2015. Tugas, Peran, Kompetensi dan Tanggung Jawab Menjadi Guru Profesional. EDUKASI: Jurnal Pendidikan. Vol. 13, No. 2

Dewi, Fatma, Aji, W. 2020. Dampak Covid-19 Terhadap Implementasi Pembelajaran dari Sekolah Dasar. Edukatif: Jurnal Ilmu Pendidikan. Vol. 2, No.1, Hal. 55-61

Jayul, Achmad; Edi Irawanto. 2020. Model Pembelajaran Daring sebagai Alternatif Proses Kegiatan Belajar Pendidikan Jasmani di Tengah Pandemi Covid-19. Jurnal Pendidikan Kesehatan Rekreasi. Vol. 6, No. 2, Hal 190-199

Gumilang, Surya, G. 2016. Metode Penelitian Kualitatif dalam Bidang Bimbingan dan Konseling. Jurnal Fokus Konseling.. Vol. 2, No. 2.

Gusty, Sri; dkk. 2020. Belajar Mandiri: Pembelajaran Daring di Tengah Pandemi Covid19. Yayasan Kita Menulis.

Hanafy, Muh. Sain. 2014. Konsep Belajar dan Pembelajaran. Jurnal Lentera Pendidikan. Vol. 17 No. 1

Juhji. 2016. Peran Guru dalam Pendidikan. Studia Didaktika: Jurnal Ilmiah Bidang Pendidikan. Vol. 10, No. 01.

Khusniyah, Nurul, L; Lukam Hakim. 2019. Efektifitas Pembelajaran Berbasis Daring: Sebuah Bukti pada Pembelajaran Bahasa Inggris. Jurnal Tatsqif: Jurnal Pemikiran dan Penelitian Pendidikan. Vol. 17, No. 1 
Limawarman, N, G; Fuad, A. 2010. Proses Kreatif Pelukis Kaligrafi Islami: Sebuah Penelitian Kualitatif. Jurnal Psikologi Proyeksi. Vol. 5. No. 1.

Nugraha, Hafiz; Ambiyar. 2018. Pengaruh Budaya Belajar Terhadap Hasil Belajar Ketrampilan Komputer dan Pengelolaan Informasi Siswa Sekolah Menengah Kejuruan Muhammadiyah 1 Padang. Jurnal Inovasi Vokasional dan Teknologi. Volume 18 Number 2.

Nugraha, Fahmi, M, dkk. 2020. Pengantar Pendidikan dan Pembelajaran di Sekolah Dasar. Tasikmalaya: Edu Publisher.

Rigianti, Henry, A. 2020. Kendala Pembelajaran Daring Guru Sekolah Dasar di Banjarnegara. Elementary School: Jurnal Pendidikan dan Pembelajaran KeSD- an. Vol. 7, No. 6

Satrianingrum, P, A; Iis, Prasetyo. 2020. Persepsi Guru Dampak Pandemi Covid-19 terhadap Pelaksanaan Daring di PAUD. Jurnal Obsesi: Jurnal Pendidikan Anak Usia Dini. Volume 5 Issue 1 (2021) Pages 633-640.

Surahman, Edy; Mukminin. 2017. Peran Guru Sebagai Pendidik dan Pengajar dalam Meningkatkan Sikap Sosial dan Tanggung Jawab Sosial Siswa SMP. HARMONI: Jurnal Pendidikan IPS. Vol. 4, No. 1

Syarifudin, Albitar, S. 2020. Implementasi Pembelajaran Daring untuk Meningkatkan Mutu Pendidikan sebagai Dampak Diterapkannya Social Distancing. METALINGUA: Jurnal Pendidikan Bahasa dan Sastra Indonesia. Vol. 5, No.1 